\title{
Global Effects in Political Ideology-Case of Kosovo
}

\author{
Burim Mexhuani, PhD Cand \\ European University of Tirana, Albania
}

\begin{abstract}
:
The paper examines the global effects on political ideologies in the case of Kosovo not only theoretical but also practical aspects. The ideological misunderstanding of political parties in Kosovo at a first reading creates the idea of a virus that has passed in many countries with consolidated democracy. In this logic, we can not claim something different to us, for how long, the claim to refer to different doctrines is viewed with much scepticism. To achieve the objectives of the paper, we have elaborated the global effects that have in the ideologies of political parties in Kosovo. The paper found that Integration into the European Communities over the years has become an indisputable priority for any government in Kosovo. The integration process changes in the government program of any political force, not just on paper. It was observed there exists International organizations such as the IMF strive, with a degree of success, to push and impose aspects of globalization in a particular direction, and such discourses, such as neoliberal economic discourse, are an important part of the strategy for to achieve this goal. The findings, therefore, suggest that through participation in democratic elections, they want to represent these interests to representatives and formal political institutions.
\end{abstract}

Keywords: Kosovo, Political parties, Ideology, Globalisation, IMF, EU

\section{Introduction}

The ideological misunderstanding of political parties in Kosovo at a first reading creates the idea of a virus that has passed in many countries with consolidated democracy. In this logic, we can not claim something different to us, for how long, the claim to refer to different doctrines is viewed with much skepticism.

There are many political scientists who advocate how socialism and capitalism are doing practices that are close to each other. In the European and global political scene, it is found a cooling and reduction of the debate and of the leftist right antagonistic positions.

Adapting a modern philosophy that is important to identify the problem, find the causes of creation and propose measures or better policies for its elimination, has oriented the left and right political forces as well as their programs Towards more pragmatic solutions in relation to social theory or social currents that they might prefer. Social processes themselves force them to do so.

The most typical example of this political philosophy is Tony Blair's political experience in England and the success of his liberal neolabouristic platform which is synthesized in ensuring the survival of binomial economic efficiency - social equality. The same philosophy and political action is also found in the analysis Of reforms or development programs in Germany, Switzerland, Denmark, Norway, Austria, Finland, Sweden, USA, etc., although in many cases the ruling parties were parties of the right-wing Christian Democrats or traditional conservatives, again a political pragmatism is Solving the problems associated with a pragmatic compromise with the parties of social democratic orientation. However, despite the similar tendencies in these countries, the Albanian context is not the same and certainly the factors that have influenced these countries for such policies do not have the same effect. Exactly, the evaluation of external and internal factors in the Albanian context is of interest, whether to "blame" the political class somewhat for ideological ambiguity but also to make it accountable for the reports it has created over the years.

\section{The Influence of Globalization in Defining Political Ideologies}

The notion of globalization is more and more described, and less defined, because it is very complex as a concept. "The word globalization in most dictionaries is interpreted as a notion that implies the world as a whole. The global surname was 
born at the end of the 19th century to mark the overall world, while the globalization name entered for the first time in the Webster dictionary in 1961. (Smith Baylis \& Owens, 2010)

Globalization, globalization, is translated as an expression: universally, the universe. Frenchs call globalization globalism. The idea of globalization has many meanings, once used in terms of direction, development of capitalism, or as a notion of the new world business paradigm as a technical term for describing economic processes, political processes and national processes. Some expressions, "globalization, are exclusively used to describe the relationship between the continents (Pelevik, 2003).

Globalization, described by Gunchenout, is very impersonal, since its concept is undefined. Determining globalization largely depends on the perspective that the author explores: the economic, social, cultural, communicative, and ecological or governance aspect.

As for Robert W. Cox (Cox, 1992), the trends of globalization include the internationalization of production, the new international labor division, the new migratory movements from the South to the North, the new competitive circles that accelerate the processes of internationalism and turn states into agencies of the world globalized. While Richard Muir (Muir, 1997) advocates that it is not a political concept, but above all, it is a phenomenon that has arisen with the development of technology, economic trends, and enterprise activity that can change political systems. For Charles Kegley (Kegey, 2008), the phenomenon of globalization is defined as the interconnection of states through the constant growth of cooperation, communications and trade that precedes the creation of the world as an integrated and dependent whole or the global system and the unique country in which processes Changes connect the same lucky people.

From various approaches to globalization, it is possible to conclude that the overall definition may include the economy, politics and culture. It is necessary to improve the broadly-conceived globalization as a global economy, as globalization is a rather complex process, while the creation of the global economy is a part of it.

Globalization for many scholars is a major challenge for state sovereignty. This is because the foreign policy of a state is dependent on supranational institutions. In essence, this independence is the willingness of the state to align its foreign policy with the policy of international institutions, regimes and norms in exchange for favors of a different kind (Thomas, J. Alfird, R. Hicks, A. Schwatz, M, 2005).

Despite the manifest process of reconciling domestic trade with global trade, which is always descriptive and shapes the national economy as a subordinate part, it is always possible but with the greatest difficulty to distinguish between national, regional and global economies. The development paradigm according to Jasna Plevnik (Plevnik, 2003) is the ideological currency of globalization, a model that will surely exist for the future, as propagating the most powerful states. According to this model, the key to the development of each country is the ability to integrate this economic system into the global economic system.

Contemporary French philosopher Alain Finkielkraut warns about the phenomenon of marginalization of the policy, the role and importance of which the economy takes. Even for Manuel Castels (Castels, 2010), politics is no longer a place of power, despite its influence still going on. While Ulrich Beck (Beck, 2000) for globalization defends the thesis that world ideology or ideology of neoliberalism develops precisely because of political activity. Economic globalization has a strong impact on international relations through the process of market, goods, services and finance integration, argues Eric Hobsbawm (Hobssbawn, 1994), but this does not mean that we have only a content of international relations in the external and internal relations of states. In Webster's vocabulary the notion of geo-economics is defined as a letter for the letter etymologically, as the activity of economic policies in the global space. The ideology of mobilizing capital is more widely represented by international organizations such as the International Monetary Fund, the OECD and the World Trade Organization. These institutions have reduced the power of the state.

World Trade Organization member states have been summoned with the aim of familiarizing themselves with their international core labor standards and reviewing the relationship between trade provisions and workers' rights. We take the case of the International Monetary Fund, which has become the lender of the Third World in order to secure the temporary loan of these countries. Loans granted to these countries conditioned the IMF to reduce overall spending, in some cases with devaluation requirements for the national currency, reducing donations to social policy by significantly curbing the areas of national independent policy (Ch, 2008). 
Since the requirement for IMF involvement comes from the government of the state which represents interest in credit, such commitment is not interpreted as a threat to sovereignty, although the definitions presented are large. The IMF has approximately uniform and rigid access to countries that become debtors in this institution and expect them to exclusively follow the financial logic. In this logic Plevnik states: states need to be highly disciplined to govern economic policy in accordance with rules dictated by the IMF, but this logic not only causes problems because the specifics of that country are not taken into account or are not allowed to take measures for which perhaps the economic situation could be advanced. No wonder that IMF role Joseph Stiglitz has labeled metaphorically as firefighters (Kegey, 2008).

Rightly Thomas, Alfird, Hicks, and Schwatz (Thomas) advocate the idea that politics has not disappeared and has not lost its impact, but in content terms it is increasingly becoming a supporter of economic activity, whereas previously the economy has been supportive of political activity. The economy thus becomes the fundamental means of political power.

This concept is accompanied by prominent sociologist Anthony Gidens when he points out: ... global social globalization through which distant countries keep in touch with one another, so that events in a particular country are characterized by the same processes as it may happen Another country miles away ... and vice versa. But, the conclusion and the best summary is given by Laurent Carroue. ... Current globalization, this geo-historical process of the progressive expansion of capitalism on a planetary scale, is at the same time a liberal ideology, a coin, a dollar, a model - capitalism, a political system, democracy, a language - English (L. Carroue, D. Collet et C. Ruiz., 2005). Some politologists have given another dimension, calling globalization ... an indicator of reconfiguration of the role of the state in relation to the actors and new challenges ... or in a more global plan a typical phenomenon of international relations ... which represents the global context in the To which all the trends and forces of force and power develop on a planetary scale. First and foremost, there is the so-called economic globalization that is closely related to the worldwide spread of services, the extraordinary mobility of capital, the workforce, innovation, technical and technological knowledge, the creation of global markets, the expansion of Firms and multinational companies and products made in world etc. This specific profile, according to many authors who have specifically addressed it, implies three dimensions: geographical (capital movement from one country to another); Functional (diversification of the capital market - monetary market, stock market, etc.); Time, (markets operate today 24 hours all over the world).

In terms of globalization, terms such as the right, left, center, left right, are subject to the same patterns. In the framework of globalist doctrine, the main objective of the action is to reduce the scope of government activity in relation to the transnational capital flow and reduce national sovereignty in decision-making in favor of decision-making power of international institutions and bodies such as: IMF, World Bank, WTO, IBRD, ALENA, EU, etc. In general, the policies pursued by these organisms by many scholars are perceived as right-wing globalization.

While the center globalization policy is estimated to be dominated by major national and international NGOs such as Oxfam, Greenpeace, MSF, ATTAC, World Social Forum, Via Campesina, etc. These organizations are thought to have a different vision in relation to the first group, expressing through their actions and allegations the sensitivity and demands of civil society to the effects of globalization.

Starting from 1995, there is a tendency to increase the power and decision-making of international institutions or groups such as the IMF, WTO, World Bank, G7, OECD, UNDP, and so on. The extreme liberalism of markets and the economy, served as the only alternative to development theories based on public funding and protectionism, began to show much weakness and inability to cope with the frequent crises of this decade. However, the years 2007 - 2008 showed that the world financial system suffered its biggest crisis since 1929 (Civici, 2009).

The internationalization of the US crisis of risky real estate loans led to drastic reductions and losses for world stock markets, provoked the bankruptcy of many banks and insurance companies and orientated the entire planet's economy into a dangerous recession. Alan Greenspan's statement to the former Federal Revolutionary President in the United States, often regarded as the cornerstone of the economy or as a magician of finance since the current crisis questioned the superiority of a free market system to which he had Always trusted, is the most significant indicator for a new page to be read in reading, understanding and applying the economy. The first line of this page was probably written by French President Sarkozy as he declared: ... the XXI century needs its capitalism, which can not be the capitalism of the last century (Civici, 2009). 
While politicians and bankers from all over the world are trying to get out of the crisis, economists and academics try to find the right lessons, to understand the causes and above all to elaborate the new economic and financial policies and models and instruments to do so Do not repeat more at the global level as well as at national levels. All governments, parties, business or public opinion are maximally interested in these conclusions that would guarantee us the non-repetition of this global situation, quite disturbing.

\section{The Role of the International Community in Defining Ideology in Kosovo}

Kosovo already has contractual relations with the European Union, meaning it is a signatory and a political-economic beneficiary through its missionary mechanisms that have long been operating in Kosovo.

Unfortunately it is known that Kosovo remains only a geographic part, and almost no political part of the EU. The EU Rule of Law Mission (EULEX) has been initiated since 2008, (It was established by the EU and is directly under the responsibility of the EU's Foreign and Security Policy Officer established through the Joint Action of the Council of the European Union (5928/08) on 4 February 2008), with a European building spirit for Kosovo, which has been intensified since the first half of 2007, when the idea of a Such a plan of establishing a mission with innovation and special modeling as a project for the EU for Kosovo.

The sole objective of the EULEX mission is to "support Kosovo towards European integration in the area of rule of law and EULEX expertise are being used in support of the EU's main goals in the visa liberalization process , Feasibility study and Pristina-Belgrade dialogue. EULEX also supports the structured dialogue on the rule of law, led by Brussels. EULEX is continuing its devotion to the fight against corruption in close co-operation with local peers to achieve the EU's solidarity and best practices in Kosovo. At the same time, EULEX is giving priority to the establishment of the rule of law in the north " (eulex-kosovo.eu, 2012) according to the Brussels plan since its mandate remained largely to assist Kosovo in strengthening security and order in co-operation with potential donors of European states, with beneficial, developmental, legal-economic, recommendation and cognitive interest for Kosovo in the processes of integration.

Integration into the European Union over these years has become an indisputable priority for any government in Kosovo. The integration process turns into the government program of any political force, not just on paper. Often, the priorities set out in the reports are more or less the government program of the ruling political and opposition power. Not only that, but the EU's reports, criticisms and assessments become the epicenter of the debate and discussions on the achievements, challenges and decisions of the present and the future. This logic [is promoted more by the public. Many consider membership in the EU as a guarantee for controlling the irresponsibility of the local political elite.

The high level of confidence in EU structures is illustrated by the results of surveys conducted by international specialized institutions. In this context, the political elite uses this indicator as a way of justifying cooperation with international institutions in general, European ones in particular and political credo. But this creates a problem from the point of view of representation. Many lectures and priorities coming from EU institutions do not necessarily reflect the main concerns of the electorate. This often creates problems with regard to representation.

For many scholars, such an approach, from a content point of view, focuses mainly on democratization technology, which is not left or right but right or wrong. On this logic, the "people" emerged in relation to its European future rather than on certain social - or in the context of an ideological universe. As long as the Albanian society emerged through its European future, it is logical that integration into the EU, symbolizing precisely this future, would turn into an end in itself. In this logic, categories such as farmers, young people, marginalized groups, civil society, small business representatives are articulated in the framework of a future European society rather than the milestones upon which this society should be established. Consequently, their special interests are subject to European integration emergencies.

According to Kaldor and Ivan in the conditions when faced with the inability to purely and simply follow the evolution of the public, we stand before the emergence of new features of politics, which distract the latter from public opinion. Here we are talking in the first place about the technical nature of politics. Often the differences between PDK and LDK are minimal, the role of ideology becomes negligible. Between them it becomes very difficult to find fundamental changes in ideology, economic policy or foreign policy. More important to be considered as a technical, procedural rather than an ideological aspect. Matrices, reforms, models, procedures, standards, dominate the discourse of political actors. 
As long as such Europeanization processes are reduced to the technical implementation of standards, procedures, laws and practices dictated by the EU, no matter which political force is in power, the issue of ideological structuring of parties remains unresolved. Much more such an approach is also stimulated by the public. This latter end is used by political forces to increase co-operation with international institutions with the ultimate goal of improving legitimacy lost to this electorate, despite the fact that this behavior often contradicts the ideological profile they claim to belong to.

Party positions related to European integration may depend largely on two main factors: the ideology or party strategy. According to Timus (2008), in the case of candidate countries, ideology may be the main factor explaining the parties' positions towards EU integration.

The EU is currently in the spotlight. Although there are debates about the future of Europe and sometimes the emergence of the Eurozone, there are also countries that are interested in becoming new members of the EU. Kosovo is also one of these countries.

LDK's policy, in relation to Kosovo's EU and NATO membership, also consists in more co-ordinated co-operation with international institutions deployed in Kosovo. LDK believes that the integration of Kosovo and the Western Balkans into the EU brings peace, prosperity and stability to this part of Europe"(LDK's political program).

The strategy used by the European Union during the enlargement process relies on giving or holding rewards, then punishing some party for unwanted and rewarding behavior of the other party for good behavior. During the integration process, the EU works with two types of rewards. The first is technical or financial assistance,

So that it becomes a market economy. The second reward consists of institutional links, such as trade links and association I association agreements, greater involvement in the EU market and finally full membership.

How successful is this conditionality strategy depends on the domestic political conditions a place?

All political parties in Kosovo are supporters of Kosovo's EU integration Other Euro-Atlantic structures, since Kosovo's goal is to build strategic partnership relations with the United States of America, to integrate the Republic of Kosovo into the European Union, NATO, the UN, and other international mechanisms (PDK's political status).

The party system in Kosovo is characterized by unpreparedness in terms of social regulation. Political parties in Kosovo, after the declaration of independence, were challenged on issues of building states. Continued support from the European community to market reforms and the European integration agenda are the two main factors that show the ambiguity of structuring the relationship between Ideology and political parties, respectively the difference between the right and the left. When we look at the programs of Albanian political parties in Kosovo and take into account the economic and political side, it is difficult to make a distinction between the left and the right. All parties promise the development of Kosovo's economy by improving the livelihoods of its citizens; Promise gradual reform, deeper social connections from the state, providing the state with a stronger position.

Political parties in Kosovo have not explicitly expressed their ideological orientation. The two largest parties in Kosovo analyzed, PDK and LDK, are considered to be center-right parties. Both parties, according to their programs, have conservative ideologies. LDK since its inception has started its political activity as a right-wing party, while the PDK starts as a left-wing party while retaining the "heir of war values", to change its party profile at the party of the center Right. Even after analyzing the programs of these center-right parties, they are almost the same and often appear to have created an ambiguity in structuring their ideological profiles.

\section{The effects of the IMF on political ideologies in Kosovo}

Kosovo's membership in these two international IMF and World Bank mechanisms will enable the country an even greater access to global monetary co-operation and the international market.

Kosovo's membership in the International Monetary Fund and the World Bank will create Kosovo's economic security, enhance its image in financial markets, and it is expected that many foreign investors will enter the Kosovo market with a much greater confidence. 
"As a member of the IMF, the state of Kosovo will enjoy an even greater access to global monetary cooperation and the international market, with this decision coming to the state of Kosovo with greater opportunities, but also with very serious responsibilities."

The International Monetary Fund and the World Bank have their offices in Kosovo since the end of the war. The World Bank has helped with some small money projects, while the IMF office has overseen the Kosovo budget (Kosovo Prime Minister Hashim Thaci: "Statement after Kosovo's membership in the IMF, June 29, 2009, available at: http://dw.com/p/lddH).

The International Monetary Fund does not support specific economic funds, but this mechanism supports economic initiatives in general and, on the occasion of allowing different credits, this mechanism requires certain reforms to be made in fiscal policy. Example on the privatization of enterprises or on the balance of payments deficit. So the essence of funding from the IMF relates to overall economic financing, for example when countries do not have sufficient liquidity to meet their external obligations. Since Kosovo's membership in the International Monetary Fund in 2009 to date, politics, media, civil society and our institutions have officially treated everything officially between Kosovo and the IMF.

Politics, seen from the point of view of the position or the opposition, have in many cases been forced under the tutelage of this institution. Be it for pragmatic reasons but also as part of the obligations stemming from the related agreement. During these years, the phrase "forces the IMF", "has set the IMF", "is an IMF estimate," etc. have been constantly present throughout these years. Our institutions have respected and have tried to maximally benefit from their performance from the IMF's "tips" and "suggestions". Every IMF mission in Kosovo, or any agreement with it, has been an event in institutional and political life in Kosovo.

To understand the role of the International Monetary Fund (IMF), it is necessary to look at the context of the circumstances that created this important mechanism for the development perspective of each country in the world. And some of this context is related to the phenomenon of globalization or the process which, apart from re-arranging (transforming) reports, primarily economic, political, social, and especially cultural, between countries, regions and continents, reorganizes and accelerates massively The process of relations between the social and financial dinosaurs such as the World Bank, Transnational Companies and the International Monetary Fund, which we are talking about, is also delightful.

The role of the IMF therefore has to do decisively with: rules, instruments, services and organizations to accurately enforce payments and credits received from countries and countries around the world.

It is the criterion of acceptance for all member countries the process of capacity verification and national assets in the exchange plan with other countries. So the height of the trade exchange rate in one way determines the voting power of the member country in this institution.

With this diopter, the question of the "weight" of each country is judged by "specific weight", which in the case of Kosovo as a small country seems extremely pernicious also due to late membership. But what is the role of this very important mechanism for countries that are still in transition?

According to many analyzes, it seems to us that the main role of this institution with planetary dimensions and tasks is largely related to: the tendencies of promoting a co-operation and the global financial institutional mediation that is imperative to holding international consultations in the field of finance only Not only to cause deficiencies and sufficiency, then to provide assistance to create an equilibrium or an equilibrium of international trade; Promoting and maintaining a constant high level of employment and income, as well as a permanent development of products, with a view to preserving a stable economy and without obvious dissolution in international relations; Creation of stable preconditions for nondiscrimination of the currencies of countries and countries across the world; As well as creating the preconditions for a single payment system between various regional and sub-regional partners, along with the various processes that go hand in hand with a multirateral exchange in the world.

In addition to the positive thoughts of this international institution, there are those who have very harsh warnings and suggestions about it. So eg. One of the greatest economists of the last century (according to most world economics experts), well-known Professor Jim Saxton (Jim Saxton), the institution of the International Monetary Fund, is recognized as one of the most arrogant, most counterproductive and most destabilizing institutions "That they have ever been able to happen to the civilized world (!), And that this international institution in essence" possesses more capital than at first glance 
impresses in the broader international opinion. Realistically the countries in transition, as a single address almost when it comes to economic development capabilities, have the IMF, but some of them are disappointed with the facts that we now have no time to elaborate even so much because They have more political reasons than economic reasons.

Kosovo, with its claims to monitor this important international institution, must nevertheless prove its integrative, but not conflicting, journey as it has done in disregard of standards for raising salaries (Maloku). It remains to be seen which of the routes will take Kosovo in the period we are entering, alongside there are many dilemmas recently displayed by different experts ...!?

\section{Conclusions}

For some experts, the 8-year experience of co-operation of all governments following the country's independence with the IMF in the framework of the agreements results to be very successful and decisive for managing public finances and maintaining the country's key macroeconomic balances. It is precisely the criteria established by this Institution that maintained the acceptable level of public debt expressed as a percentage of GDP; The budget deficit, also expressed as a percentage of GDP, reforming the social security system. Any deviation from IMF standards in these indicators may provoke a chain of effects of the type: price hikes, inflation, lower purchasing power, debt growth, public spending cuts, shocks to macroeconomic balances, unemployment, fictitious and superficial development. The role of the IMF has been the financial and economic stability in general, which they have offered. Whereas, the World Bank which has offered grants has now turned it into a loan form for the results to be expected.

Precisely, this fact makes the IMF's presence with its recommendations and certifications for the performance of our financial system as positively positive from the point of view but also imposing. However, if we look at this role of the IMF from an ideological perspective, we notice that its role significantly limits the ability to stay strictly assigned to a certain doctrinal profile.

The moments where this aspect of the IMF can be tested are the privatization processes of former public enterprises. Almost all small and medium-sized enterprises were privatized under the IMF's "blessing".

The 2.7 percent growth of Kosovo's economy for 2014 has been appreciated by non-optimistic tones from the country's central bank.

The public sector in Kosovo remains the main sector of employment. Meanwhile, the International Monetary Fund (IMF) in the concluding statement of Kosovo's economic assessment, published on March 30, 2015, highlights specifically employment in the public sector as one of the risks for the country's economy's sustainability. During the presentation of this report, it was emphasized that this growth was made possible by the increase of public sector wages (as a result) the growth of lending by consumer credit and remittance banks, while foreign investments experienced a drastic decline of about 50 percent.

Meanwhile, the International Monetary Fund (IMF) in the closing statement of Kosovo's economic assessment, published on March 30, 2015, highlights the overcrowding in the public sector as one of the risks for the country's economy's sustainability. However, in June 2015, Kosovo has reached agreement with the International Monetary Fund for economic reform. "This program fully addresses the needs of the state of Kosovo, Kosovo's economy to provide future development opportunities.

It is worth underlining the fact that following the IMF guidelines has influenced the behavior of political forces in relation to their possible identities. No matter what political force has been in power, each has had to follow its guidelines and recommendations in order to benefit from its expertise and the funds it accords to cooperative countries. A legitimate attitude towards some of the political parties for the country's own development stage. The need to gain experience and to participate in international bodies was accompanied by conditionalities that governments, despite the political wing, were obliged to fulfill. As we tried to explain above, governments, regardless of the political wing they belonged, maintained the same line as regards the implementation of guidelines set by the IMF.

\section{References}

[1] Almond, G., \& Verba, S. (1989). The Civic Culture: Political Attitudes And Democracy In Five Nations. Sage. 
[2] Arend Lijphart. (1999). Patterns of Democracy. Government Forms and Performance in Thirty-Six Countries . New Haven and London: Yale University Press.

[3] Aristoteli. (2002). Politika. Tiranë: CEU.

[4] Beck, U. (2000). What is Globalization?, . Oxford: Polity Press .

[5] Castels, M. (2010). Castels, M. (2010) The Power of Identity, . London and New York: Wiley Blackwell .

[6] Ch, K. (2008). World Politics: Trend and Transformation. Cengage Learning .

[7] Civici, A. (2009). Globalizimi. Tirana: UET press.

[8] Cox, W. R. (1992). Multilaterismm and Democracy,. Retrieved from http://www.acuns.org/membersubm/johnholmes/globalizat

[9] eulex-kosovo.eu. (2012, November 08). Retrieved from eulex-kosovo.eu: http://eulexkosovo.eu/al/info/whatisEulex.php

[10] Heywood, A. (2007). Political ideologies, An introduction. Palgrave: Macmillan.

[11] Hobssbawn, E. (1994). Epoka e Ekstremeve. Tirana: Cabej.

[12] Kegey, C. (2008). World Politics: Trend and Transformation,. Cengage Learning .

[13] L. Carroue, D. Collet et C. Ruiz. (2005). La Mondalization, Genese, acteurs et enjeux. Breal .

[14] Mackie, G. (2003). Schumpeter's Leadership Democracy. San Diego: University of California.

[15] Maloku, F. (n.d.). Developing countries have the IMF single developmental address, while Kosovo itself. Retrieved from http://telegrafi.com

[16] Muir, R. (1997). Political geography: A new introduction,. UK: Macmillan Education UK.

[17] Ostrogorski, M. L. (2009). Democracy and the Organization of Political Parties. The United States, New York:: Transaction Publishers .

[18] Pelevik, J. (2003). Pas Globalizimit, Prishtine: Kolegji Universitar Victory. Pristina: Kolegji Universitar Victory.

[19] Platoni. ( 2002). Republika. Tiranë: CEU.

[20] Plevnik, J. (2003). Pas globalizimit, Tiranë: Golden Marketing, . Tirana: Golden Marketing.

[21] Sartori, G. (1993). Edhe një herë për teorinë e demokracisë. Tiranë: Dituria.

[22] Smith Baylis \& Owens. (2010). The Globalization of World Politics, , p. 4. London: Oxford University Press.

[23] Tushi, G. (2007). Shoqëria Civile",. Tiranë: Dudaj.

[24] Thomas, J. A. (n.d.). The Handbook of Political Sociology: States, civil societies and globalization. 2005: Cambridge University Press.

[25] Thomas, J. Alfird, R. Hicks, A. Schwatz, M. (2005). The Handbook of Political Sociology: States, civil societies and globalization. Cambridge University Press.

[26] Walzer, M. M. (1992). The Civil Society Argument in C. Mouffe, Dimensions of Radical. New York: Verso.

[27] Zaleski, P. S. (2008). Tocqueville on Civilian Society. A Romantic Vision of the Dichotomic Structure of Social Reality. 